\title{
Tıp Fakültesi Son Sınıf Öğrencilerinin Sağlam Çocuk İzlemi Hakkındaki Bilgi Düzeylerinin Değerlendirilmesi
}

\section{Evaluation of Knowledge Level of The Last Year Medical Students About Well Child Monitoring}

\author{
${ }^{1}$ Meltem YILMAZ, ${ }^{2}$ Mustafa Kürşat ŞAHIN \\ ${ }^{1}$ Tokat Pazar İlçe Devlet Hastanesi, Başhekimlik, Tokat, Türkiye \\ ${ }^{2}$ Ondokuz Mayıs Üniversitesi Tıp Fakültesi Aile Hekimliği Anabilim Dalı, Samsun, Türkiye \\ Meltem Y1lmaz: https://orcid.org/0000-0003-3623-9585 \\ Mustafa Kürşat Şahin: https://orcid.org/0000-0002-3490-6009
}

\section{ÖZ}

Amaç: $\mathrm{Bu}$ çalışmada son sınıf tıp öğrencilerinin sağlam çocuk izlemi hakkındaki bilgi düzeylerinin değerlendirilmesi ve eğitim ihtiyaçlarının saptanması amaçlanmıştır.

Materyal ve Metot: Tanımlayıcı tipteki bu çalışmaya 01.02.2018 ile 01.09.2019 tarihleri arasında eğitim gören 145 son sınıf tıp öğrencisi katılmıştır. Sistematik örnekleme yöntemi kullanılmıştır. Verilerin toplanmasında anket formu kullanılmıştır. Ankette yaş, cinsiyet, medeni durum, pediatri stajı alma durumu ve sağlam çocuk izlemi ile ilgili 21 adet bilgi değerlendiren soru bulunmaktadır.

Bulgular: Çalışmaya aile hekimliği stajını yapmakta olan 80 'i $(\% 55,2)$ kadın, 65'i $(\% 44,8)$ erkek olmak üzere toplam 145 kişi katılmıştır. Katılımcıların yaş ortalaması $24,2 \pm 1,36$ y1l idi. 86 's1 $(\% 59,3)$ pediatri stajını yapmış, 56 'sı $(\% 40,7)$ henüz pediatri stajını yapmamıştı. Bilgi düzeyini ölçmeye yönelik olan 21 sorunun toplam puanı 21 olarak değerlendirildi. Katılımcılar ortalama 7,32 $\pm 2,63$ puan aldi. Cinsiyet, medeni durum ve pediatri staj1 yapma ile sağlam çocuk izlemi hakkındaki bilgi düzeyleri arasında istatistiksel bir fark saptanmamıştır.

Sonuç: Katılımcılar sağlam çocuk izlemi ile ilgili bilgi sorularının ortalama olarak sadece üçte birini biliyordu ve tam puan alan yoktu. Ayrica pediatri stajı yapmak ile de ortalama puanlarda bir artı̧̧ görülmedi. Sağlam çocuk izlemi ile ilgili eğitim ihtiyacının olduğu net olarak ortaya konmuştur.

Anahtar Kelimeler: Bilgi düzeyi, sağlam çocuk izlemi, tıp öğrencileri

\section{ABSTRACT}

Objective: This study aimed to evaluate interns' level of knowledge about well-child care visits and determine their educational needs.

Materials and Methods: 145 last-year medical students from 01.02.2018 to 01.09.2019 participated in this descriptive study. A systematic sampling method was used. A questionnaire form was used to collect data. The questionnaire includes 21 questions evaluating information about well-child care visits and age, gender, marital status, pediatric internship status.

Results: A total of 145 people, 80 women (55.2\%) and 65 men $(44.8 \%)$, participated in the study. The mean age of the participants was $24.2 \pm 1.36$ years. $6(59.3 \%)$ of them completed their internship in pediatrics, $56(40.7 \%)$ of them did not do a pediatrics internship yet. The total score of 21 questions aimed to measure the level of knowledge was evaluated as 21 . The mean score of the participants was $7.32 \pm 2.63$.

Conclusions: There was no statistically significant difference between gender, marital status, and internship in pediatric and knowledge about well-child care visits. On average, the participants knew only one-third of the information questions about well-child care visits and did not receive a full score. Also, there was no increase in average scores with an internship in pediatrics. It is demonstrated that there is a need for education regarding well-child care visits.

Keywords: Knowledge level, medical students, well-child care
Sorumlu Yazar / Corresponding Author:

Meltem Yilmaz

Tokat Pazar İlçe Devlet Hastanesi, Başhekimlik

Tel: +90 $3562614075-1212$

E-mail: drmelteyilmaz@yahoo.com
Yayın Bilgisi / Article Info:

Gönderi Tarihi/ Received: 23/12/2020

Kabul Tarihi/ Accepted: 09/04/2021

Online Yayın Tarihi/ Published: 05/06/2021

Atıf / Cited: Yılmaz M ve Kürşat Şahin M. Tıp Fakültesi Son Sınıf Öğrencilerinin Sağlam Çocuk İzlemi Hakkındaki Bilgi Düzeylerinin Değerlendirilmesi. Online Türk Sağlık Bilimleri Dergisi 2021;6(2):216-223. doi: 10.26453/otjhs.845731 


\section{GÍRIŞ}

Hastalık belirtileri olmayan, takvim yaşıyla paralel bir bedensel gelişme, fizyolojik büyüme, ruh ve zekâ gelişimi olan çocuklara sağlam çocuk denir . Sağlam çocuk takibi, çocuk sağlığı hizmetlerinin birinci basamaktaki en önemli noktasıdır. ${ }^{1}$ Bu izlem, yalnızca sağlam çocuklara verilen bir hizmet değil, bütün çocukların büyüme ve gelişimlerinin takip edildiği, iyilik hallerinin değerlendirildiği, aşılama, otizm ve görme taramalarının yapıldığı ve sağlıklı olma halinin devam ettirilmesi adına koruyucu hekimliği kapsayan bir çocuk sağlığ 1 hizmetidir. Sağlam çocuk takibiyle çocukların sağlıklı halinin devam etmesi, olası hastalıkların erken teşhis edilmesi, mortalite ve morbiditelerin azaltılması hatta önlenmesi amaçlanmaktadir. $^{2}$

Sağlam çocuk izlemi; bebeklikten başlayıp çocukluk ve ergenlik döneminde devam eden düzenli sağlık kontrollerinden oluşan, uzun soluklu bir takiptir. $\mathrm{Bu}$ izlem doktor, aile, aile sağlığı elemanı işbirliğiyle yürütülmeli, çocuk değerlendirilirken içinde bulunduğu ortam ile bir bütün olarak ele alınmalıdır. ${ }^{2}$ Ülkemizde sağlam çocuk izleminde önerilen standart programında; doğumda, ilk 48 saat içinde, 15., 41. günde, 2., 3., 4., 6., 9., 12. ayda, 13 ile 36 ay aras1 6 ayda bir, 4-9 yaş arası yılda bir, ergenlik boyunca da en az 3 kez olmak üzere izlem yapılması önerilmektedir. $^{3}$

Ülkemizde, tıp fakültelerinin sayılarının artması ile tıp eğitiminin iyileştirilmesi, temel standartların oluşturulması için 2001 yılında önemli bir adım atılarak "Ulusal Çekirdek Eğitim Programı" (UÇEP) çalışmalarına başlanmıştır. En son UÇEP-2014'ün 2015-2016 eğitim öğretim yılı ile birlikte tüm tıp fakültelerinde uygulamaya konması kararlaştırılmıştır. UÇEP-2014'te çocuk ve yenidoğan muayeneleri, bebek ve çocukta antropometrik ölçümler, çocukta büyüme ve gelişmeyi izleme, bağışıklık hizmetlerini yürütebilme, anne-çocuk sağlığı, çocuk ihmal ve istismarı gibi çocuk izlemi basamaklarının tüm tıp fakültelerinin müfredatlarında yer alarak öğrencilere öğretilmesi beklenmektedir. ${ }^{4}$

Ülkemizde sağlam çocuk izlemi Aile Sağlığı Merkezlerinde (ASM) aile hekimleri tarafindan yapılmaktadır. Bu durumda mezun olan tüm hekimlerin sağlam çocuk izlemi hakkında bilgi sahibi olmaları beklenmektedir. Bu çalışmada son sınıf tıp fakültesi öğrencilerinin sağlam çocuk izlemi hakkında bilgi düzeylerinin değerlendirilmesi ve eğitim ihtiyaçlarının saptanması amaçlanmıştır.

\section{MATERYAL VE METOT}

Çalışmanın etik kurul onayı Ondokuzmayıs Üniversitesi Klinik Araştırmalar Etik Kurulundan alındı (sayı no: B.30.2.ODM.0.20.08/1409).

Tanımlayıcı tipteki bu çalışmanın evrenini son sınıfta eğitim gören 225 tıp öğrencisi oluşturmaktadır. Çalışmaya 01.02.2018 ile 01.09.2019 tarihleri arasında eğitim gören 145 son sınıf tıp öğrencisi sistematik örnekleme yöntemi ile dâhil edilmiştir. Bu çalışma için literatür taranarak bir anket formu oluşturulmuştur. ${ }^{1-6}$ Ankette yaş, cinsiyet, medeni durum, pediatri stajı alma durumu ve sağlam çocuk izlemi ile ilgili bilgilerini değerlendiren 21 adet soru bulunmaktadır. Çalışmamız için hazırladığımız ankette bilgi düzeyini ölçmeye yönelik olan 21 soru için bir puanlama sistemi oluşturuldu. Her soru için 1 puan verildi, toplam 21 puan üzerinden değerlendirme yapıldı. Anket formu öğrencilere aile hekimliği stajı için geldikleri dönemde yüz yüze uygulanmıştır.

Verilerin Değerlendirilmesi: Elde edilen veriler IBM SPSS 22 (Statistical Package for Social Sciences Version 22) programında değerlendirildi. Kategorik veriler sayı ve yüzde olarak; numerik veriler ortalama \pm standart sapma olarak verildi. Verilerin normal dağılımı Kolmogorov Smirnov testi ile değerlendirildi. Verilerin karşılaştırılmasında kikare, Fisher's exact test ve student t testi kullanıldı. Çalışmada $\mathrm{p}<0,05$ istatistiksel olarak anlamlı kabul edildi.

\section{BULGULAR}

145 öğrencinin 80’i (\%55,2) kadın, 65'i (\%44,8) erkekti. Katılımcıların 141'i (\%97,2) bekâr, 4’ü (\% 2,8) evli idi. Katılımcıların yaş ortalaması $24,2 \pm 1,36$ y1ldı (minimum 21 yıl, maksimum 30 yıl). Öğrencilerin 86'sı (\%59,3) pediatri stajını almışken, 59'u (\% $40,7)$ henüz intörnlük dönemindeki bu stajı almamışt1.

Bebekte bir yaşına kadar olan izlem sayısını erkeklerin kadınlardan daha iyi bildiği, doğumda bebeğe yapılması gereken uygulamaları ve fiziksel istismar bulgularını kadınların erkeklerden daha iyi bildiği görülmüştür ( $p=0,145,0,031,0,02)$. Sağlam çocuk izlemi hakkındaki bilgiler ile cinsiyete göre karşılaştırma Tablo 1'de sunulmuştur.

Bebekte ilk izlem zamanını, doğumda bebeğe yapılması gereken uygulamaları, aşı takibi için ek bir izlem gerekmediğini ve yenidoğan tarama programında (NTP) taranan hastalıkları pediatri stajını yapanların yapmayanlara göre daha iyi bildiği görüldü. Güncel aşı takvimini ve prematüre (SGA) veya dü- 
şük doğum ağırlıklı (LBW) bebeklerde demir desteğinin başlanma zamanını pediatri stajını yapmayanların yapanlara göre daha iyi bildiği görülmüştür. Sağlam çocuk izlemi hakkındaki bilgiler ile pediatri stajı alma durumuna göre karşılaştırma Tablo 2' de sunulmuştur.

Son sınıf öğrencilerinin sağlam çocuk takibi bilgi düzeyinde toplam puanları 2 ile 14 arasında değişmekte olup ortalama 7,32 $\pm 2,63$ olarak görüldü

Kadınların sağlam çocuk takibi ile ilgili puan ortalamas1 7,54 $\pm 2,52$ iken erkeklerin puan ortalamas1 $7,05 \pm 2,75$ idi. Kadın ve erkeklerin ortalama puanları arasında anlamlı bir fark yoktu $(p=0,265)$. Evliler sağlam çocuk takibi bilgi düzeyi sorularından ortalama 5,75 $\pm 2,63$ puan almışken, bekârların ortalama puanı 7,36 $\pm 2,62$ idi. Evli ya da bekâr olma durumu ile ortalama puan arasında anlamlı bir ilişki izlenmedi $(p=0,228)$. Pediatri stajını yapanların sağlam çocuk izlemi ile ilgili bilgi düzeyi sorularından aldıklar1 ortalama puan $7,31 \pm 2,15$ iken, henüz pediatri staj1 yapmayanların ortalama puanı 7,32 $\pm 3,22$ idi. Pediatri stajı yapmanın sağlam çocuk izlemi bilgi düzeyinde bir etkisi olmadığı görüldü $(\mathrm{p}=0,987)$.

\section{TARTIŞMA VE SONUÇ}

Sağlam çocuk izlemi çocuk sağlığı hizmetlerinin birinci basamaktaki en önemli noktası olması sebebiyle tıp fakültesi son sınıf öğrencilerinin bu konudaki bilgi düzeylerini değerlendirdiğimiz çalışmamız öğrencilerin bilgi düzeyini gösteren puanlarının oldukça düşük olduğunu gösterdi. Ayrıca aldıkları toplam puanların pediatri stajını yapmış olma durumuyla da artmaması dikkat çekici idi.

Türkiye Nüfus ve Sağlık Araştırması 2013 verilerine göre bebeklerin \%5,4'üne ilk izlem yapılmamışken, izlemlerin \%65,3'ü 24 saat içinde yapılmıştır. ${ }^{6}$ Sağlık Bakanlığı (SB) ilk izlemin doğumda yapılmasını önermektedir. ${ }^{3}$ Bizim çalışmamızda da ilk izlem zamanı katılımcıların \%80,7'si tarafından bilindiği, bilenlerin yarısından fazlasının kadın ve pediatri stajını yapmış olduğu görüldü. Türkiye'de ve Amerika'da yapılan çalışmalar bebeklere yapılan izlemlerin SB ve Amerikan Pediatri Akademisi'nin önerilerinin çok altında olduğunu ve ilerleyen yaşla yapılan izlemlerin azaldığını göstermiştir. ${ }^{7,8}$ En yüksek izlem infant döneminde olmasına rağmen bu dönemde yapılacak izlem sayısı hakkında öğrencilerin bilgi düzeyi çalışmamızda oldukça düşük görüldü. Bilgi düzeyindeki bu eksiklik izlemlerin yeterli seviyede yapılamamasının nedenlerinden biri olabilir.

Ülkemizde 18 yaşın altındaki tüm çocukların sağlık harcamaları devlet tarafından karşılanmasına rağ- men, sağlam çocukların hekime kontrol amaçlı getirilme oranı oldukça düşüktür. Çocukların sağlam çocuk izlemine getirilmemeleri, bazı ailelerin hasta olmadan da çocukların izlenmesi gerektiğini bilmemeleri, kırsal kesimde yaşayan ailelerin ulaşım problemleri nedeniyle çocuklarını getirememeleri ile açıklanabilir. ${ }^{9}$ Ailelere sağlam çocuk izleminin önemini anlatmak hekimlerin ve tüm sağlık personelinin görevlerindendir, etkin bir şekilde anlatılabilmesi için öncelikle hekimlerin yeterli bilgiye sahip olması gerekmektedir. İzlem sıklığı ile ilgili bilgi düzeyinin pediatri stajını yapma durumu ile ilişkili olmaması, bu konuda pediatri eğitiminin önemli bir eksikliğini göstermektedir.

Uddin ve ark.'nın yaptığı çalışmada izlem için 1-5 yaş arası \%74, 6-11 yaş arası \%31 başvuru varken, adölesan dönemi 12-17 yaş arasında bu oran \%29 olmuştur. ${ }^{10}$ Yılmaz'ın çalışmasında aile hekimlerin sadece beşte biri sağlam çocuk izleminin adölesan dönemde de sürmesi gerektiğini belirtmişti. ${ }^{5}$ Bizim çalışmamızda ergenlik döneminde en az 3 izlem yapılması ve izlemlerin 21 yaşına kadar devam etmesi gerektiğini belirtenlerin oranı çok düşüktü.

Yılmaz'ın yaptığı çalışmada sahada çalışan aile hekimlerinin \%38,7'si tarafından işitme taramasının zamanı doğru bilinmekte iken bizim çalışmamızda bu oran \%81,4'tü. ${ }^{5}$ Yapılan çalışmalarda sağlam çocuk izleminde \%90'dan fazla oranlarda boy, kilo ölçümü rutin olarak yapılmıştır. ${ }^{9,10}$ Bizim çalışmamızda katılımcıların büyük çoğunluğu sağlam çocuk izleminde bebeğin boy ve kilosunun ölçülmesi, baş çevresi ölçümü ve fontanel muayenesi, işitme taramasının yapılması, vücut 1sısının ölçülmesi, kırmızı yansıma refleksi bakılması gerektiğini biliyordu. Boy ve kilo ölçümü yapılması gerektiğini düşünen kişi sayısı ile sahada çocukların boy ve kilosunun ölçülmesi oranı benzer görülmüştür.

Çelik ve ark.'nın çalışmalarında rutin izleme gelen çocukların \%39,3'ünde persentil sapması gözlenmiştir. ${ }^{11}$ Bizim çalışmamızda çocukta büyüme parametrelerini katılımciların \%26,2'si biliyordu. Persentillerde düşüşün önemli bir beslenme eksikliğinin ilk göstergesi olabileceğini, kontrollerde hekimlerce persentillerin değerlendirilip beslenme eksikliğinin erken tanınabilmesi oldukça önemli iken, öğrencilerde bu konuda önemli bilgi eksikliği vardı. Yılmaz'ın çalışmasında hekimlerin yalnızca \% 20,9'u obezite tanısı için kullanılan persentil üst sınırını biliyordu. ${ }^{5}$ Bizim çalışmamızda persentil eğrilerinin alt ve üst sınırlarını katılımcılardan \% 64,8 'i biliyordu. Bu yüksek oran toplumdaki artan çocukluk çağı obezitesi ile ilişkili olabilir. 
Bebeklere doğumda Hepatit B aşısının yapılma oranlarıyla çalışmamızda doğumda Hepatit B aşısının yapılması gerektiğini bilme oranı benzerdi. ${ }^{12,13}$ Hepatit B aşı ile ilgili hem kendi pratikleri hem kadın doğum, pediatri ve enfeksiyon stajlarında yer alması bilinirliğini artıran bir faktör olabilir. Doğumda bebeklere uygulanan $\mathrm{K}$ vitamini profilaksisinin intrakraniyal kanama olasılığını \% 100 'e kadar engellediği yapılan çalışmalarla gösterilmiştir. ${ }^{14-16} \mathrm{Bu}$ kadar hayati olan doğumda $\mathrm{K}$ vitamini profilaksisi uygulanması gerekliliğini katılımc1larımızın \%82'si bilmekteydi.

Yılmaz'ın çalışmasında güncel aşı takviminde olmayan aşıları hekimlerin \%87,4'ü biliyorken, ${ }^{5}$ bizim çalışmamızda aşı takvimine yeni eklenen aşıları bilme oranı \%9,7 idi. Çalışmamızda güncel aşı takvimini takibin sahadaki hekimlere oranla bu denli düşük olması mevcut eğitimin bu konudaki içerik ve güncelliğinde eksiklikler olduğunu düşündürmektedir.

Yapılan çalışmalar ailelerin aşılama veya hastalık olmadığı sürece izlem için hekime gitmenin gerekmediği, aşılamanın çocuk izleminin bir parçası olmadığı inancında olduklarını göstermektedir. ${ }^{9,17} \mathrm{Bi}$ zim çalışmamızda rutin aşı takvimindeki aşıların yapılması için ek bir izlem yapılmasına gerek olmadığını, aşılamanın izlemin bir parçası olduğunu katılımcılarımızın büyük çoğunluğu biliyordu.

Sağlık çalışanlarınca ailelere yenidoğan taramaları, bu taramalarla erken saptanan hastalıkların tedavisinin mümkün olduğu konusunda bilgi verilmesi anne ve babaların kaygılarının azalmasına, tarama programlarına katılımların artmasına katkı sağlayacaktır. ${ }^{18,19}$ Yılmaz'ın çalışmasında NTP'deki hastalıkların hepsini bilen aile hekimi oranı \%9,9 idi. ${ }^{5}$ Bizim çalışmamızda NTP'yi doğru bilenlerin oranı \%13,8 olarak bulundu. Hekimlerin ve hekim adaylarının yenidoğan taramaları hakkında yeterli bilgilerinin olmaması ailelere bu konuda gerekli bilgilendirilmelerin yapılamamasının nedenlerinden biri olabilir.

Küçük ve Göçmen'in yaptığı çalışmada katılımcıların \%83,3'ü düzenli olarak demir profilaksisini kullanıyordu, kullanmayan grupta ise en önemli neden öneminin yeterince anlatılmamasıyd $1 .{ }^{20}$ Karapınar ve ark.'nın yaptığı çalışmada çocukların \%16'sı hiç demir profilaksisi almamış, prematür ve matür bebeklerin profilaksi alması arasında anlamlı bir fark bulunamamıştır. Uygun profilaksi dozunun ise çocukların ancak \%40'ında kullanıldığı görülmüştür. ${ }^{21}$ Yılmaz'ın çalışmasında hekimlerin \%85'inin demir profilaksisinin 4. ayda başlanması gerektiğini bildiği görülmüştür. ${ }^{5}$ Bizim çalışmamızda katılımcıların \% 34,5'i term bebekte demir profilaksisi başlanması gereken zamanı biliyordu. Yılmaz'ın çalışmasında demir profilaksisi başlanma zamanını bilme oranının bizimkinden çok daha yüksek olması sahada bakanlık tarafından düzenli olarak demir preparatlarının dağıtılmasının katkısı olabilir. Toplum yönelimli olmayan bir tıp eğitimi, tıp öğrencilerinin sahada yapılan uygulamalardan uzakta kalmasına neden olmaktadir.

Dünyanın birçok yerinde D vitamini ile ilgili epidemiyolojik çalışmalar mevcuttur, çocuk ve ergenlerde \%7 ila 68 arasında değişen D vitamini eksikliği bildirilmiştir. $^{22}$ Çataklı ve ark.'nın yaptığı çalışmada annelerin tamamı çocuklarına günde 3 damla $D$ vitamini vermesi gerektiği bilgisine sahip olmasına rağmen sadece \%67,2'si bebeklerine düzenli D vitamini veriyordu. Günde 3 damla D vitamini verilmesi bilgisini annelerin \%50,6's1 ASM'lerden öğrendiğini söyledi. ${ }^{23}$ Bizim çalışmamızda da katılımcıların \% 51'i D vitamini profilaksi dozunu doğru biliyordu. Hatun'un yaptığı çalışmada birinci basamakta çalışan pratisyen hekimlerin \% 54'ünün bütün bebeklere $\mathrm{D}$ vitamini önerdiği, D vitamini dozu ve süresi konusunda da yanlış bilgilerinin olduğu saptanmıştır. ${ }^{24}$ Yılmaz'ın çalışmasında hekimlerin yalnızca \%9,4'ü term yenidoğanda D vitaminin birinci günde başlanması gerektiğini biliyordu. D vitamini profilaksi dozunu ise hekimlerin \%76,9'unun bildiği görüldü. ${ }^{5}$ Bizim çalışmamızda öğrencilerin \%43,4’ü D vitamini başlama zamanını doğru biliyordu. Sahada çalışan hekimlere göre bu oranın oldukça yüksek olması umut vericidir. Doğru profilaksi dozu ise katılımcıların \%51'i tarafından bilinmektedir. Bu oran Yılmaz'ın çalışmasına göre daha düşük görülmüştür. ${ }^{5}$

Gölge ve ark.'nın sağlık çalışanlarına çocuk istismarı ve ihmali ile ilgili yaptığı çalışmada katılımcıların yarısından çoğu bu konuyla ilgili eğitim gördüklerini belirtmiştir, doktorların \% 86,5'i, istismar ve ihmal konusunda bilgiye ihtiyaçları olduğunu ifade etmiştir. $^{25}$ Üniversite öğrencilerine yönelik yapılan çalışmalar çocuk istismarı ve ihmali hakkındaki bilgi düzeylerinin yeterli olmadığını ortaya koymaktadır. $^{26,27}$ Demir'in Edirne ilinde ASM'lerde çalışan hekimlere yaptığı çalışmada çocuk istismarı ve ihmaline yönelik bilgi düzeyi kadınlarda istatistiksel olarak anlamlı düzeyde daha yüksekti. ${ }^{28}$ Fiziksel istismarın bıraktığı izlerin açıkça görülmesi nedeniyle tanınması, belirlenmesi daha kolay olabilir. Hizmet içi eğitimlerde ihmal ve istismar tüm yönleriyle ele alınmalıdır. Kara ve ark.'nın hekimlerin bilgi düzeyinin kadınlarda ve evlilerde anlamlı derecede yüksek olduğunu bildirmişlerdir. ${ }^{29}$ Bizim çalışma- 
mızda da fiziksel istismarın muayene bulgularını bilme ile kadın cinsiyet arasında anlamlı bir ilişki izlendi.

Yılmaz'ın birinci basamakta sağlam çocuk izlemi ile ilgili yaptığı çalışmasında alınan ortalama puan bizim çalışmamızdakinden yüksekti. Yılmaz'ın ve bizim çalışmamızda ortalama puan ile medeni durum ve cinsiyet arasında anlamlı ilişki saptanmamıştir. ${ }^{5}$

Çalışmamızın bazı kısıtlılıkları bulunmaktadır. Birincisi çalışmamız tek tıp fakültesinde yapıldığı için genelleme yapılması uygun değildir. İkincisi aile hekimliği stajı öncesi ve sonrası değerlendirme yapılmamıştır. Çalışma sonrasında müfredat değerlendirmesi yapılarak sağlam çocuk izleminin müfredatta bir bütün olarak yer almadığı görüldü. Bununla ilgili eğitim kurullarına önerilerde bulunuldu. Aynı zamanda sağlam çocuk izlemi ile ilgili aile hekimliği stajı kapsamında intörnlük döneminde bebek-çocukadölesan izlemi ile ilgili kapsamlı eğitimler eklendi. Üçüncüsü, bu konuda tıp öğrencilerinde yapılmış olan ulusal ya da uluslararası düzeyde ulaşılabilen literatürün yetersiz olması nedeniyle tartışma kısmında sağlık çalışanları ile yapılan çalışmalar kullanılmıştır. Çalışmanın güçlü yanı ise tıp öğrencilerinin sağlam çocuk izlemi ile ilgili bilgi düzeylerini değerlendiren ilk çalışma olmasıdır. Bilgi eksikliğinin giderilmesi için hem preklinik hem klinik dönemde eklenmiş olan derslerin etkilerinin değerlendirileceği çalışmalara ihtiyaç vardır. Aynı zamanda çok merkezli mezuniyet öncesi ve sonrası sağlam çocuk izlemi ile ilgili çalışmalar ile konunun kapsamlı olarak değerlendirilmesi uygun olacaktır.

UÇEP-2014'te sağlam çocuk izlemi basamakları ve bağışıklama uygulamalarının tıp eğitimi müfredatında yer alması gerektiği belirtilmişken ${ }^{4}$, öğrencilerin bu konudaki bilgileri oldukça yetersiz görülmektedir. Mevcut tıp eğitimin sonunda yer alan tıpta uzmanlık sınavının nadir görülen birçok durum ve hastalıklarla ilgili detaylı bilgilerle dolu olması, sık görülen ve toplumun büyük kısmını etkileyen birçok durum veya hastalığın daha az önemsenmesi ile sonuçlanmaktadır. Diğer yandan tanı ve tedavi edici hizmetlerin ön planda tutulması, koruyucu sağlık hizmetlerinin ise daha arka planda kalması bunun diğer bir nedeni olabilir. Koruyucu sağlık hizmetlerinden sadece bir tanesi olan sağlam çocuk izlemlerinin ele alındığı bu çalışmada tıp öğrencilerinin bu konudaki bilgi eksiklerinin olduğu saptanmıştır.

Etik Komite Onayı: Çalışmamız Ondokuz Mayıs Üniversitesi Klinik Araştırmalar Etik Kurulu (Tarih:
09/02/2018, Karar no: 2018/39) tarafindan onaylandi.

Çıkar Çatışması: Yazarlar çıkar çatışması bildirmemektedir.

Yazar Katkılart: Fikir - MY., MKŞ.; Denetleme MKŞ; Malzemeler - MY., MKŞ.; Veri toplanması ve işlemesi - MY., MKŞ.; Analiz ve yorum - MY., MKŞ.; Yazıyı yazan - MY., MKŞ.

Hakem değerlendirmesi: Dış bağımsız.

\section{KAYNAKLAR}

1. Vitrinel A, Erdağ G. Sağlam çocuk izlemi. Türkiye Aile Hekimliği Dergisi. 2007; 11(3):101 -106 .

2. Gür E. Sağlam Çocuk İzlemi. İstanbul Üniversitesi Cerrahpaşa Tıp Fakültesi Sürekli Tıp Eğitimi Etkinlikleri. Ekim 2003, İstanbul, Türkiye.

3. Sağlık Bakanlığı. Bebek, çocuk, ergen izlem protokolleri. https://hsgm.saglik.gov.tr/depo/ birimler/cocuk_ergen_db/dokumanlar/yayinlar/ Kitaplar/Bebek_Cocuk_Ergen_Izlem__Protokolleri_2018.pdf. Erişim tarihi 17 Ağustos 2020.

4. Gülpınar MA, Gürpınar E, Songur A, Vitrinel A. Mezuniyet öncesi tıp eğitimi ulusal çekirdek eğitim programı 2014. https://www.ktu.edu.tr/ dosyalar/medtip_752c6.pdf. Erişim tarihi 17 Ağustos 2020.

5. Yılmaz T, Şencan I, Yılmaz T, ve ark. The assessment of knowledge levels and practices of family physicians practicing in family health centers in Ankara with regard to well child follow-up. Ankara Med J. 2018;18(3):312-321. doi:10.17098/amj.461402.

6. Hacettepe Üniversitesi Nüfus Etütleri Enstitüsü Ankara. Türkiye nüfus ve sağlık araştırması, 2013. http://www.hips.hacettepe.edu.tr/tnsa2013/ rapor/TNSA_2013_ana_rapor.pdf. Erişim tarihi 17 Ağustos 2020.

7. Korkmaz A, Aydın Ş, Çamurdan A, ve ark. Türkiye'de bebek ölüm nedenlerinin ve ulusal kayıt sisteminin değerlendirilmesi. Çocuk Sağlığı ve Hastalıkları Dergisi. 2013;56(3):105-121.

8. Goyal NK, Brown CM, Folger AT, Hall ES, Van Ginkel JB, Ammermen RT. Adherence to wellchild care and home visiting enrollment associated with increased emergency deparment utilization. Matern and Child Health J. 2020;24(1):7381. doi:10.1007/s10995-019-02821-5

9. Topal Y, Topal H, Battaloğlu İnanç B, Özkoç H. Türkiye'de sağlam çocuk izlemi verilerinin değerlendirilmesi. MMJ. 2017;4(2):6-10. 
10. Uddin SG, O'Connor KS, Ashman JJ. Physician office visits by children for well and problemfocused care: United States, 2012. NCHS Data Brief. 2016;(248):1-8.

11. Çelik SB, Şahin F, Beyazova U, Can H. Growth status of children in well-baby outpatient clinics and related factors. Turk Pediatri Ars. 2014;49 (2):104-110. doi:10.5152/tpa.2014.1145

12. Oster NV, Williams EC, Unger JM, ve ark. Sociodemographic, clinical and birth hospitalization characteristics and infant Hepatitis B vaccination in Washington State. Vaccine. 2019;37(38):5738 -5744. doi:10.1016/j.vaccine.2019.03.050

13. Myers HI, Spracklen CN, Ryckman KK, Murray JC. A retrospective study of administration of vaccination for hepatitis $\mathrm{B}$ among newborn infants prior to hospital discharge at a midwestern tertiary care center. Vaccine. 2015;33(20):23162321. doi:10.1016/j.vaccine.2015.03.053

14. Katar S, Özbek MN, Güzel A, Devecioğlu C, Ecer S. Yenidoğanlarda $\mathrm{K}$ vitamini eksikliğine bağlı intrakranial kanama. Çocuk Sağlığı ve Hastalıkları Dergisi. 2006;49(4):296-300.

15. Tıraş Ü, Aral YZ, Yıldırmak Y, Özkan H, Dallar Y. Yenidoğanın hemorajik hastalığını önlemede intramuskuler ve oral $\mathrm{K}$ vitamini etkinliğinin karşılaştırılması. Turkiye Klinikleri J Pediatr. 2004;13(2):63-66.

16. Karapınar B, Yilmaz D, Arslan M, Kavaklı K. Sağlıklı süt çocuklarında ciddi intrakraniyal kanama: K vitamini profilaksisinin önemi. ETD. 2004;43(1):29-32.

17. Goedken AM, Urmie JM, Polgreen LA. Factors related to receipt of well-child visits in insured children. Matern Child Health J. 2014;18(3):744754. doi:10.1007/s10995-013-1301-2

18. Arnold CL, Davis TC, Frempong JO, ve ark. Assessment of newborn screening parent education materials. Pediatrics. 2006;117(3):320-325. doi:10.1542/peds.2005-2633L

19. Al-Sulaiman A, Kondkar AA, Saeedi MY, Saadallah A, Al-Odaib A, Abu-Amero KK. Assessment of the knowledge and attitudes of saudi mothers towards newborn screening. Biomed Res I n t. $\quad 20015 ; 2015: 718674$. doi:10.1155/2015/718674

20. Küçük Ö, Göçmen AY. Çocuk polikliniğine başvuran 6-24 ay arası sağlam çocukların değerlendirilmesi. Med J Bakirkoy. 2012;8(1):28-33. doi:10.5350/BTDMJB201208105

21. Karapinar TH, Bildik O, Köker SA, ve ark. The evaluation of taking iron supplements in children aged 6 months-2 years. J Pediatr Res. 2017;4 (3):156-159. doi:10.4274/jpr.37790

22. Saggese G, Vierucci F, Boot AM, ve ark. Vitamin D in childhood and adolescence: an expert position statement. Eur J Pediatr. 2015;174 (5):565-576. doi:10.1007/s00431-015-2524-6

23. Çataklı T, Taşar S, Oğulluk M, Dallar BY. Bir hastaneye başvuran annelerin $\mathrm{D}$ vitamini hakkındaki bilgileri ve kullanma tutumları. ETD. 2014;53(3):135-140.

24. Hatun Ş. Günümüzde D vitamini yetersizliği sorunu. Turkiye Klinikleri J Pediatr Sci. 2006;2 (11):42-46.

25. Gölge ZB, Hamzaoğlu N, Türk B. Sağlık çal1şanlarının çocuk istismarı ve ihmali konusundaki farkındalık düzeylerinin ölçülmesi. Adli Tıp Dergisi. 2012; 26(2):86-96.

26. Türkkan T, Çakıcı, AB, Bülbül K. Sosyal hizmet bölümü öğrencilerinin çocuk istismarı ve ihmali hakkındaki bilgi düzeylerinin incelenmesi: Gümüşhane Üniversitesi örneği. Toplum ve Sosyal Hizmet. 2020;31(2):368-388. doi:10.33417/ tsh.643971

27. Taş A. Hacettepe Üniversitesi öğrencilerinin çocuk ihmal ve istismarı hakkındaki bilgi düzeylerinin incelenmesi. Hacettepe Üniversitesi Sosyal Bilimler Enstitüsü Sosyal Hizmet Anabilim Dalı, Yüksek Lisans. Ankara, Türkiye. 2017.

28. Demir H. Edirne ili aile sağlığı merkezlerinde görevli hekimlerin çocuk istismarı ve ihmali hakkında bilgi, farkındalık ve tutumlarının belirlenmesi. Trakya Üniversitesi Tıp Fakültesi Aile Hekimliği Anabilim Dalı, Uzmanlık Tezi. Edirne, Türkiye. 2013.

29. Kara Ö, Suskan E, Çalışkan E. Ankara ilinde görev yapan çocuk asistanları, uzmanları ve pratisyen doktorların çocuk istismarı ve ihmali konusunda bilgi düzeyleri ve yaklaşımlarının karşılaştırılması. Türk Pediatri Arşivi. 2014;49 (1):57-65. 
Tablo 1. Sağlam çocuk izlemi hakkındaki bilgiler ile cinsiyete göre karşılaştırma.

\begin{tabular}{|l|c|c|c|c|}
\hline & Toplam & Kadın & Erkek & \\
\hline Sağlam çocuk izlemi ile ilgili ifadeler & $\mathbf{N}(\mathbf{\%})$ & $\mathbf{N}(\mathbf{\%})$ & $\mathbf{N}(\mathbf{\%})$ & $\mathbf{p}^{*}$ \\
\hline Bebekte ilk izlem zamanını bilme & $117(80,7)$ & $68(58,1)$ & $49(41,9)$ & 0,145 \\
\hline Bebekte bir yaşına kadar olan izlem sayısını bilme & $40(27,6)$ & $16(40,0)$ & $24(60,0)$ & 0,023 \\
\hline Bir ila dokuz yaş arası izlem aralıklarını bilme & $33(22,8)$ & $19(59,6)$ & $14(42,4)$ & 0,752 \\
\hline Adölesan izlemlerini bilme & $13(9,0)$ & $6(46,2)$ & $7(53,8)$ & 0,493 \\
\hline İlk bir yaş izlemlerinde yapılması gereken muayeneleri bilme & $17(11,7)$ & $11(64,7)$ & $6(35,3)$ & 0,400 \\
\hline Büyüme ve gelişme değerlendirme parametrelerini bilme & $38(26,2)$ & $20(52,6)$ & $18(47,4)$ & 0,714 \\
\hline Persentil eğrilerinin alt ve üst sınırını bilme & $94(64,8)$ & $51(54,3)$ & $43(45,7)$ & 0,763 \\
\hline Doğumda bebeğe yapılması gereken uygulamaları bilme & $79(54,5)$ & $50(63,3)$ & $29(36,7)$ & 0,031 \\
\hline Güncel aşı takvimini takip etme & $14(9,7)$ & $9(64,3)$ & $5(35,7)$ & 0,471 \\
\hline Aşı takibi için ek bir izlem gerekmediğini bilme & $131(90,3)$ & $72(55,0)$ & $59(45,0)$ & 0,876 \\
\hline Yenidoğan tarama programındaki (NTP) taranan hastalıkları bilme & $20(13,8)$ & $11(55,0)$ & $9(45,0)$ & 0,987 \\
\hline $\begin{array}{l}\text { Prematüre (SGA) veya düşük doğum ağırlıklı (LBW) bebeklerde demir } \\
\text { desteğinin başlanma zamanını bilme }\end{array}$ & $48(33,1)$ & $29(60,4)$ & $19(39,6)$ & 0,372 \\
\hline SGA veya LBW olan bebeklerde demir desteği dozunu bilme & $52(35,9)$ & $29(55,8)$ & $23(44,2)$ & 0,914 \\
\hline Term bebeklerde demir desteğinin başlanma zamanını bilme & $50(34,5)$ & $28(56,0)$ & $22(44,0)$ & 0,884 \\
\hline Term bebeklerde demir desteği dozunu bilme & $74(51,0)$ & $39(52,7)$ & $35(47,3)$ & 0,542 \\
\hline Bebeklerde D vitamini başlama zamanını bilme & $63(43,4)$ & $36(57,1)$ & $27(42,9)$ & 0,676 \\
\hline Bebeklerde D vitamini profilaksi dozunu bilme & $74(51,0)$ & $44(59,5)$ & $30(40,5)$ & 0,289 \\
\hline Bebekte sevk kriterlerini bilme & $8(5,5)$ & $6(75,0)$ & $2(25,0)$ & 0,297 \\
\hline Fiziksel istismar bulgularını bilme & $61(42,1)$ & $43(70,5)$ & $18(29,5)$ & 0,020 \\
\hline Gelişimsel kalça displazisi (GKD) taranma zamanını bilme & $33(22,8)$ & $16(48,5)$ & $17(51,5)$ & 0,379 \\
\hline GKD’nin öykü ve klinik bakı ile taranması gerektiğini bilme & $2(1,4)$ & 0 & $2(100,0)$ & - \\
\hline
\end{tabular}

p: Ki-kare testi; N: Sayı; \%: Tablo yüzdesi. 
Tablo 2. Sağlam çocuk izlemi hakkındaki bilgiler ile pediatri stajı alma durumuna göre karşılaştırma.

\begin{tabular}{|l|c|c|c|c|}
\hline & Toplam & $\begin{array}{c}\text { Pediatri } \\
\text { stajı } \\
\text { yapan }\end{array}$ & $\begin{array}{c}\text { Pediatri } \\
\text { stajı yap- } \\
\text { mayan }\end{array}$ & p \\
\hline Sağlam çocuk izlemi ile ilgili ifadeler & $\mathbf{N}(\mathbf{\%})$ & $\mathbf{N}(\mathbf{\%})$ & $\mathbf{N}(\mathbf{\%})$ & \\
\hline Bebekte ilk izlem zamanını bilme & $117(80,7)$ & $77(65,8)$ & $40(34,2)$ & 0,001 \\
\hline Bebekte bir yaşına kadar olan izlem sayısını bilme & $40(27,6)$ & $19(47,5)$ & $21(52,5)$ & 0,074 \\
\hline Bir ila dokuz yaş arası izlem aralıklarını bilme & $33(22,8)$ & $18(54,5)$ & $15(45,5)$ & 0,526 \\
\hline Adölesan izlemlerini bilme & $13(9)$ & $6(46,2)$ & $7(53,8)$ & 0,312 \\
\hline İlk bir yaş izlemlerinde yapılması gereken muayeneleri bilme & $17(11,7)$ & $9(52,9)$ & $8(47,1)$ & 0,569 \\
\hline Büyüme ve gelişme değerlendirme parametrelerini bilme & $38(26,2)$ & $23(60,5)$ & $15(39,5)$ & 0,859 \\
\hline Persentil eğrilerinin alt ve üst sınırını bilme & $94(64,8)$ & $58(61,7)$ & $36(38,3)$ & 0,426 \\
\hline Doğumda bebeğe yapılması gereken uygulamaları bilme & $79(54,5)$ & $53(67,1)$ & $26(32,9)$ & 0,037 \\
\hline Güncel aşı takvimini takip etme & $14(9,7)$ & $3(21,4)$ & $11(78,6)$ & 0,002 \\
\hline Aşı takibi için ek bir izlem gerekmediğini bilme & $131(90,3)$ & $82(62,6)$ & $49(37,4)$ & 0,014 \\
\hline Yenidoğan tarama programındaki (NTP) taranan hastalıkları bilme & $20(13,8)$ & $16(80)$ & $4(20)$ & 0,043 \\
\hline SGA veya LBW bebeklerde demir desteğinin başlanma zamanını bilme & $48(33,1)$ & $21(43,8)$ & $27(56,3)$ & 0,007 \\
\hline SGA veya LBW olan bebeklerde demir desteği dozunu bilme & $52(35,9)$ & $26(50)$ & $26(50)$ & 0,088 \\
\hline Term bebeklerde demir desteğinin başlanma zamanını bilme & $50(34,5)$ & $27(54)$ & $23(46)$ & 0,345 \\
\hline Term bebeklerde demir desteği dozunu bilme & $74(51)$ & $41(55,4)$ & $33(44,6)$ & 0,328 \\
\hline Bebeklerde D vitamini başlama zamanını bilme & $63(43,4)$ & $39(61,9)$ & $24(38,1)$ & 0,577 \\
\hline Bebeklerde D vitamini profilaksi dozunu bilme & $74(51)$ & $41(55,4)$ & $33(44,6)$ & 0,328 \\
\hline Bebekte sevk kriterlerini bilme & $8(5,5)$ & $7(87,5)$ & $1(12,5)$ & 0,142 \\
\hline Fiziksel istismar bulgularını bilme & $61(42,1)$ & $39(63,9)$ & $22(36,1)$ & 0,334 \\
\hline Gelişimsel kalça displazisi (GKD) taranma zamanını bilme & $33(22,8)$ & $24(72,7)$ & $9(27,3)$ & 0,074 \\
\hline GKD’nin öykü ve klinik bakı ile taranması gerektiğini bilme & 0 & 0 & 0 & - \\
\hline
\end{tabular}

p: Ki-kare testi; N: Sayı; \%: Tablo yüzdesi. 